\title{
The calcium and phosphorus intakes of rural Gambian women during pregnancy and lactation
}

\author{
BY ANN PRENTICE*, M. ANN LASKEY, JACQUIE SHAW, \\ GEOFFREY J. HUDSON, KENNETH C. DAY, LANDING M. A. JARJOU, \\ BAKARY DIBBA AND ALISON A. PAUL \\ Medical Research Council Dunn Nutrition Unit, Downhams Lane, Milton Road, \\ Cambridge CB4 IXJ, UK, and Keneba, The Gambia
}

(Received 30 December 1991-Accepted 5 August 1992)

\begin{abstract}
The Ca and $P$ intakes of 148 pregnant and lactating women in a rural village in The Gambia, West Africa, have been estimated by direct weighing of food on a total of $4188 \mathrm{~d}$. The $\mathrm{Ca}$ and $\mathrm{P}$ contents of local foods were determined by analysis of raw ingredients, snack foods and prepared dishes. Information about the contribution of mineral-rich seasonings was obtained. Efforts were made to discover unusual sources of $\mathrm{Ca}$ that might not be perceived as food by subject or observer. The main contributors to daily Ca intake were shown to be leaves, fish, cereals, groundnuts and local salt. Cow's milk accounted for only $5 \%$ of $\mathrm{Ca}$ intake. Unusual sources of $\mathrm{Ca}$ were discovered, namely baobab (Adansonia digitata) fruit and selected earths, but these were consumed infrequently and their contributions to $\mathrm{Ca}$ intakes were small. Cereals and groundnuts were the main sources of $P$. Ca and $P$ intakes $(\mathrm{mg} / \mathrm{d})$ were shown to average 404 (SD 110) and 887 (SD 219) respectively. Seasonal changes in the availability of leaves, cereals and groundnuts resulted in variations in $\mathrm{Ca}$ and $\mathrm{P}$ intakes. The rainy season was associated with increased Ca intakes (by $16 \%$ ) but decreased $P$ consumption (by $15 \%$ ). No difference was observed in Ca intake between pregnant and lactating women but $P$ intake in lactation was $11 \%$ higher than that in pregnancy during the post-harvest season. The implications of these low $\mathrm{Ca}$ intakes require investigation.
\end{abstract}

Calcium: Phosphorus: Pregnancy: Lactation

$\mathrm{Ca}$ intakes are reputed to vary widely between different regions of the world (Food and Agriculture Organization/World Health Organization, 1962; Prentice, 1991). The lowest intakes are reported from communities where animal milks are scarce or not habitually consumed, as is the case in many parts of Africa and Asia (Prentice, 1991). Dietary surveys in these areas indicate that average Ca intakes by adults may be as $10 \mathrm{w}$ as $300-500 \mathrm{mg} / \mathrm{d}$ $(7.5-12.5 \mathrm{mmol} / \mathrm{d})$. In addition, the amount of $\mathrm{Ca}$ absorbed from predominantly vegetarian diets may be low due to high intakes of phytates and oxalates (e.g. Food and Agriculture Organization/World Health Organization, 1962; Allen, 1982; Hongo et al. 1989; Pun et al. 1991). Such intakes are considerably below current recommendations (Truswell et al. 1983; Department of Health, 1991). This is particularly striking for women in traditional societies who have elevated requirements for many years due to repeated pregnancies and long lactational periods.

The ability of standard dietary surveys to assess accurately $\mathrm{Ca}$ intakes in traditional societies has been challenged (Harris, 1945; Baker \& Mazess, 1963). A number of unusual

* For reprints. 
Ca-rich dietary components have been identified that could make significant contributions to $\mathrm{Ca}$ intakes. Examples include wild leaves, fruits and roots eaten by certain Australian, African and American tribes (Wehmeyer, 1966; Wehmeyer et al. 1969; Brand et al. 1982; Norton et al. 1984; Eaton \& Nelson, 1991) and pica and ash eaten by South American Indians (Baker \& Mazess, 1963). It is claimed by some authors that, as a result, Ca intakes in such communities are high (Eaton \& Konner, 1985) and that this may account for the low incidence of osteoporosis in these areas. However, these claims are based primarily on qualitative estimates and little detailed information is available on the frequency or quantities of these foods consumed.

Mandinka women in rural parts of The Gambia, West Africa, are pregnant or lactating for much of their early adult lives. Their diet is based primarily on cereals and groundnuts and, as milk is rarely consumed, it would be predicted that their habitual Ca intakes would be low. The aim of the present study was to combine a comprehensive investigation of the $\mathrm{Ca}$ and $\mathrm{P}$ contents of local foods with quantitative information on the dietary intakes of rural Mandinka women during pregnancy and lactation. Emphasis was placed on the identification and analysis of unusual foods that might contribute little to energy or protein intakes but that might enhance mineral consumption significantly. The present detailed investigation demonstrated that the daily Ca intakes of rural Gambian mothers are indeed very low, averaging about $400 \mathrm{mg} / \mathrm{d}(10 \mathrm{mmol} / \mathrm{d})$, and that the predominant sources of $\mathrm{Ca}$ in this region are leaves and fish.

\section{METHODS}

The study took place in the rural, farming community of Keneba, The Gambia. This Mandinka village has been the centre of intensive nutritional studies by the Dunn Nutrition Unit since 1974 (Prentice, 1985). The investigators had a thorough knowledge of the dietary practices of the villagers due to long periods spent in the village and to the able assistance of Gambian field staff.

The diet in Keneba is predominantly vegetarian, based on rice (mano, Oryza sativa), millets (sanyo, Pennisetum typhoideum; suno, Pennisetum gambiense; kinto, Sorghum margaritiferum ; findo, Digitaria exilis) and groundnuts (tio, Arachis hypogaea). Animal milk (cow and goat) is consumed only occasionally, either fresh or soured. Meat (cow, goat, sheep, chicken) is eaten rarely, usually on special occasions, but fish, fresh or dried, is consumed regularly. Most plant foods are grown by the village; the main exception being rice, most of which is purchased as imported, polished rice. The soil of the region is predominantly laterite except for the salt flats adjacent to the rivers. Full details of foods consumed in Keneba and their methods of preparation have been described by McCrae \& Paul (1979). A brief glossary of Mandinka cooking terms is given in Table 1.

The diet in this area is highly seasonal. The year can be divided into three periods: the rainy season from July-October, the dry, post-harvest season from November-March and the hot, dry pre-farming season from April-June. The rainy season is characterized by low stocks of cereals and groundnuts, high agricultural work-loads, high infection rates and weight loss by pregnant and lactating mothers. Wild leaves and fruits are plentiful at this time of year. During the dry, post-harvest season, cereal and groundnut supplies are good, farm work is light and the nutritional status of the mothers improves. The supply of bush food stops, but in years when water is plentiful the women grow vegetables such as tomato, onion, okra (Hibiscus esculentus) and chili pepper (Capsicum frutescens). Cereal and groundnut stocks begin to be limited in the hot, pre-harvest season. The women are occupied in preparing farm land for the rains, the supply of garden vegetables ceases but mangoes are plentiful. 
Table 1. The frequency of consumption of major food categories by pregnant and lactating Gambian women May 1978-April 1979

\begin{tabular}{|c|c|c|}
\hline $\begin{array}{l}\text { Main } \\
\text { ingredient }\end{array}$ & Gambian dishes* & $\begin{array}{c}\text { Frequency } \\
(\%)\end{array}$ \\
\hline \multicolumn{3}{|c|}{ Staple dishes $\ddagger(n 7476) \S$} \\
\hline Rice & Fajiringo, nyankatango & 57 \\
\hline Findo & Nyelengo, futo (nyankatango) & 16 \\
\hline Sanyo & Nyelengo, futo (serengo, nyankatango) & 9 \\
\hline Kinto & Nyelengo, futo (serengo, nyankatango) & 9 \\
\hline Maize & Nyelengo, futo, roasted cobs (nyankatango) & 5 \\
\hline Cassava & Boiled, raw & 2 \\
\hline Wheat & Cracked wheat $\|$, bread & 2 \\
\hline \multicolumn{3}{|c|}{ Sauces $\div$ ( $n$ 5042)§ } \\
\hline Groundnut & Tia durango & 70 \\
\hline Leaf & Jambo, kucha & 24 \\
\hline Flour & Bukolo & 1 \\
\hline Others & e.g. oil stew, palm fruit stew & 5 \\
\hline \multicolumn{3}{|c|}{ Porridges $\ddagger(n$ 2061) $\S$} \\
\hline Rice & Mono, sato, bero, churo, tiakere churo & 33 \\
\hline Sanyo & Mono, sato & 25 \\
\hline Kinto & Mono, sato & 19 \\
\hline Wheat $\|$ & Mono & 13 \\
\hline Findo & Mono, sato & 5 \\
\hline Maize & Mono, sato, bero & 3 \\
\hline Cassava & Mono & 1 \\
\hline Locust bean & Mono & 1 \\
\hline
\end{tabular}

* Water content $(\mathrm{g} / \mathrm{kg}$ ) shown in parentheses; for further details, see McCrac \& Paul (1979) and Hudson et al. (1980): staples: fajiringo, serengo, steamed and boiled (660); nyankatango, steamed, boiled + groundnuts $(630)$; nyelengo, steamed + dried baobab leaf (630); futo, steamed, dry + dried baobab leaf (390); sauces: tia durango, roast groundnuts, tomato, \pm fish/meat, \pm vegetables $(800)$; kucha, kucha leaf, \pm fish, \pm vegetables $(870)$; jambo, fresh leaf not kucha, \pm groundnuts, \pm fish, \pm vegetables $(780)$; bukolo, cereal flour, tomato, \pm onions, \pm fish (880); dajiwo, thin soup (950); porridges: mono, thin porridge (880); sato, bero, thicker porridge (860); churo, thick porridge (830); tiakere churo, thick porridge+groundnuts $(830)$; uncommon dishes are shown in parentheses.

+ Frequency as a percentage of all foods of the same category.

\ost dishes contain salt; all porridges are made with water but milk may be added.

$\$$ Total no. of records per food category.

$\|$ An aid-food to The Gambia in 1978.

\section{Calcium content of Gambian foods}

Samples of many raw ingredients and prepared dishes were collected for analysis during the period 1976-90. The samples were frozen or dried to constant weight in a microwave oven before shipment to Cambridge.

The samples chosen for analysis may be divided into three main categories: (1) foods that formed the main-stay of the Keneba diet, (2) seasonings used in the preparation of dishes, and (3) unusual items and snacks, particularly those that might not be perceived as food by either the investigator or the subject. The items for analysis were identified during detailed interviews with village women and from local knowledge. Samples were collected at different times of the year to ensure that examples of highly seasonal foods were obtained. Drinking water was collected from several wells in the village and from domestic clay storage pots.

Quantitative recipe information and the identification of occasional components were obtained by weighing all the ingredients used in the preparation of whole meals. This part 
of the study was conducted in the homes of the village women and several hundred meals were observed.

The samples were analysed in Cambridge after dry ashing at $500^{\circ}$ and acid digestion, using $\mathrm{N}_{2} \mathrm{O}$ atomic absorption spectrometry for $\mathrm{Ca}$ and the Fiske-Subbarow method for $\mathrm{P}$ (Paul \& Southgate, 1978).

\section{Daily calcium and phosphorus intakes of pregnant and lactating mothers}

Rural Gambian women have their first baby shortly after menarche, breast-feed each child for about 2 years and continue with regular cycles of pregnancy and lactation throughout their reproductive lives. In order to estimate the daily $\mathrm{Ca}$ and $\mathrm{P}$ intakes of Mandinka women during pregnancy and lactation, use was made of a database of dietary measurements collected in Keneba between May 1978 and April 1979. Previous analyses of these data had demonstrated marked seasonal variations in energy intakes among Keneba women with low overall energy intakes but no particular deficit in protein intakes (Paul \& Muller, 1980; Prentice et al. 1981).

All pregnant and lactating women in Keneba between May 1978 and April 1979 had taken part in the dietary study ( $n$ 148, aged 1443 years). Each subject was studied for a full day, $1 \mathrm{~d}$ every week throughout her pregnancy and lactation. Field workers visited the mother several times daily, weighing and describing all foods eaten at meals and recording any snacks consumed (Paul \& Muller, 1980; Prentice et al. 1981). Mothers who were pregnant or lactating in May 1978 were included in the study and mothers who become pregnant after this date were enrolled as they were identified. The number of days of dietary estimations performed per individual ranged from $1-47$ (median $32 \mathrm{~d}$ ). Forty-five mothers were studied during one lactational period and during either the preceding or subsequent pregnancy. Three additional mothers were studied during two lactational periods and the intervening pregnancy. The total numbers of pregnancy and lactation periods studied, therefore, were 75 and 124 respectively. The total number of d of dietary measurements was 4188, comprising 17514 separate measurements of food dishes, accompaniments and snacks. Keneba villagers are occasionally the recipients of small quantities of food-aid. In 1978-9 a limited amount of cracked wheat was available. Use of cracked wheat by study subjects was recorded on only sixty-three occasions, representing an insignificant contribution to the diet.

Each food consumed was identified in the database by a two-letter code. $\mathrm{Ca}$ and $\mathbf{P}$ values were assigned after considering the measured contents in samples of food, as described previously, and the observed frequency of use of occasional ingredients. Additional information for foods not analysed was obtained from Platt (1962), FAO/US Department of Health, Education and Welfare (1968), Paul \& Southgate (1978) and West et al. (1988).

\section{RESULTS}

\section{The Keneba diet in 1978-9}

The diet pattern of the pregnant and lactating women in 1978-9 consisted of two main meals daily, eaten in the early afternoon and evening. These meals typically consisted of a cereal dish with a sauce made from groundnuts, leaves or vegetables. Breakfast was eaten by some women but not by all and not at all times of year, and was usually a cereal porridge.

Table 1 details the pattern of food dishes eaten by the women. Rice was eaten on $57 \%$ of occasions when the meal included a staple dish, with or without a sauce. Millets (findo, sanyo, suno and kinto) comprised $34 \%$ of staple dishes, eaten primarily as nyelengo or futo (Table 1). The use of findo and maize was highly seasonal, occurring towards the end of 
the rainy season. Tia durango, a sauce made from roast groundnuts, was prepared on $70 \%$ of occasions when sauces were eaten. Leaf-sauces were eaten predominantly in the rainy season and accounted for $24 \%$ of all sauces. Porridges were made mainly from rice, sanyo and kinto. The use of milk, usually as an addition to porridge, was recorded on 370 occasions (equivalent to once on $9 \%$ of study days), $65 \%$ as fresh, powdered or tinned milk, $35 \%$ as sour milk.

Records of snacks between meals were common, the main snack foods being groundnuts, handfuls of prepared food and, in season, fruits (e.g. oranges, mangoes), cassava and roast maize cobs.

\section{The calcium and phosphorus content of foods}

The measured $\mathrm{Ca}$ and $\mathrm{P}$ contents of a selection of the raw ingredients and prepared foods collected in Keneba are given in Tables 2-5. The drinking water contained insignificant amounts of either of the minerals (Table 2).

The main sources of $P$ were shown to be cereals, groundnuts and fish. The intake of $P$ by an individual, therefore, would be expected to depend on the quantities of main foods eaten. In contrast, the richest sources of $\mathrm{Ca}$ were found to be foods that are used either in small quantities as condiments or only occasionally; dried baobab (Adansonia digitata) leaf, dried fish, baobab fruit, local salt, locust beans (Parkia biglubosa) and fresh leaves.

Dried baobab leaf is used in a variety of dishes. In particular, it is frequently added to steamed millets (sanyo, suno, kinto and findo) in amounts sufficient to impart a slippery texture. The high $\mathrm{Ca}$ content of prepared nyelengo and futo dishes reflects the presence of dried baobab leaf (compare kinti serengo and kinti nyelengo in Table 3). The dry flesh of the baobab fruit (sito) is used occasionally to flavour porridge and, when added, makes a significant contribution to the Ca content.

Dried fish is used as an occasional ingredient of sauces and nyankatango. Dried chalo (Table 4) is used more frequently than other fish. The mineral content of dried fish, as eaten, was shown to be highly dependent on the mode of preparation. Dried furo, a small fish, is prepared by removing the head and tail, then pounding the bones into the flesh. Similar steps are taken for preparing dried chalo, a medium-sized fish, but large bones are also removed. Dried kujalo and other large fish are pounded after the removal of all skin and bones. Consequently dried furo contains approximately ten times more Ca than other dried fish (Table 4).

The preparation of fresh fish was also shown to influence the mineral content of the edible portion (Table 4). Chalo contains numerous whiskery bones that cannot be removed easily and are often eaten. Larger bones are always discarded. Furo has needle-sharp bones; all are picked clean and not swallowed. Kujalo and other large fish are eaten off the bone. As a consequence, boiled chalo flesh, as eaten, contains the greater amount of $\mathrm{Ca}$ (Table 4). Tiny furo (kojay-furundingo), that are eaten whole, were found to be highly Carich (Table 4). However, these fish are eaten very rarely, when food is in very short supply, and are likely to make an insignificant contribution to overall $\mathrm{Ca}$ intakes.

Fresh leaves are used in leaf sauces and occasionally as minor ingredients in tia durango. The most commonly used leaves are kucha, morongo and jambanduro (Table 5). The preparation of fresh leaves differs between varieties and this was found to modify the mineral content of the food as eaten (Table 5). Jambanduro requires soaking, boiling and draining before use. This procedure reduces the $\mathrm{Ca}$ and $\mathrm{P}$ content (Table 5). Morongo is usually washed, drained and boiled before use and the cooking water retained for cooking. This reduces the $\mathrm{P}$ content with little effect on the Ca content. Kucha leaves are steeped in water for about $30 \mathrm{~min}$ and drained before use, leading to some reduction in mineral content. Softer leaves are generally used untreated or after a quick rinse. The three most 
Table 2. Calcium and phosphorus contents of some locally obtained raw ingredients of the Keneba (The Gambia) diet

(Values are means and standard deviations for indicated no. of separate pooled samples analysed)

\begin{tabular}{|c|c|c|c|c|c|c|}
\hline \multirow[b]{2}{*}{ Description } & \multirow[b]{2}{*}{ Local name } & \multicolumn{2}{|c|}{$\begin{array}{c}\mathrm{Ca} \\
(\mathrm{mg} / \mathrm{kg})^{*}\end{array}$} & \multicolumn{2}{|c|}{$\underset{(\mathrm{mg} / \mathrm{kg})^{*}}{\mathrm{P}}$} & \multirow[b]{2}{*}{$n$} \\
\hline & & Mean & $\mathrm{SD}$ & Mean & SD & \\
\hline Rice, polished & Mano & 60 & 10 & 2490 & 250 & 3 \\
\hline \multirow[t]{3}{*}{ Millet, whole grain } & Sanyo & 90 & 50 & 3520 & 740 & 3 \\
\hline & Kinto & 120 & 50 & 3040 & 880 & 4 \\
\hline & Findo & 350 & - & 1560 & - & 1 \\
\hline Groundnuts & Tio & 450 & 90 & 2600 & 350 & 5 \\
\hline Dried baobab (Adansonia digitata) leaf & $\mathrm{Naa}$ & 17500 & - & 1930 & - & 1 \\
\hline Baobab fruit powder & Sito & 3900 & 440 & 350 & 30 & 3 \\
\hline Locust bean (Parkia biglubosa) seed & Nete tuo & 4490 & 130 & 2820 & 330 & 3 \\
\hline Locust bean-pod powder & Nete munko & 1270 & - & 1600 & - & 2 \\
\hline Cow's milk (N'dama cattle) & Ninsi nono & 1280 & - & 930 & - & 1 \\
\hline Local salt & Ko & 2750 & - & 一 & & 1 \\
\hline Sugar & Sukuro & 20 & - & 一 & & 1 \\
\hline Well water & Jio & 10 & 10 & 0 & 0 & 13 \\
\hline
\end{tabular}

* To convert $\mathrm{Ca}$ and $\mathrm{P}$ results to $\mathrm{mmol} / \mathrm{kg}$, divide by 40 and 31 respectively.

Table 3. The measured calcium and phosphorus content of selected Gambian dishes, as eaten by pregnant and lactating Keneba (The Gambia) women*

(Mean values and standard deviations)

\begin{tabular}{|c|c|c|c|c|c|c|c|}
\hline \multirow[b]{2}{*}{ Mandinka name } & \multirow[b]{2}{*}{ Description } & \multicolumn{3}{|c|}{$\mathrm{Ca}(\mathrm{mg} / \mathrm{kg}) \dagger$} & \multicolumn{3}{|c|}{$\mathrm{P}(\mathrm{mg} / \mathrm{kg}) \dagger$} \\
\hline & & Mean & SD & $n$ & Mean & SD & $n$ \\
\hline \multicolumn{8}{|c|}{ Cereal dishes and other staples } \\
\hline Mani fajiringo & Rice, boiled & 60 & 30 & 21 & 340 & 30 & 8 \\
\hline Mani nyankatango & Rice + groundnuts, steamed & 110 & 50 & 14 & 690 & 250 & 16 \\
\hline Mani mono & Rice porridge & 50 & 10 & 5 & 120 & 60 & 3 \\
\hline Mani mono+ nono & Rice porridge + milk & 100 & 70 & 3 & 350 & - & 1 \\
\hline Tiakere churo & Rice $\&$ groundnut porridge & 60 & 20 & 6 & 290 & 130 & 6 \\
\hline Sanyo nyelengo & Millet (sanyo), steamed & 310 & 60 & 6 & 950 & 270 & 8 \\
\hline Sanyo futo & Millet (sanyo), steamed, dry & 570 & 220 & 6 & 1620 & 140 & 5 \\
\hline Sanyo mono & Millet (sanyo) porridge & 50 & 10 & 8 & 130 & 110 & 11 \\
\hline Kinti serengo & Millet (kinto), boiled & 40 & 10 & 7 & 280 & 40 & 4 \\
\hline Kinti nyelengo & Millet (kinto), steamed & 250 & 180 & 14 & 840 & 560 & 9 \\
\hline Kint futo & Millet (kinto), steamed, dry & 560 & 180 & 14 & 2190 & 670 & 11 \\
\hline Kinti mono & Millet (kinto) porridge & 30 & 20 & 8 & 290 & 170 & 4 \\
\hline Tubanyo nyelengo & Maize, steamed & 300 & - & 2 & 880 & - & 2 \\
\hline Tubanyo futo & Maize, steamed, dry & 560 & 260 & 6 & 1690 & 210 & 3 \\
\hline Nyambi mono & Cassava porridge & 70 & 20 & 5 & 60 & - & 2 \\
\hline \multicolumn{8}{|l|}{ Basic sauces } \\
\hline Tia durango & Roast groundnut sauce & 210 & 80 & 22 & 690 & 190 & 16 \\
\hline Jambo & Leaves \& groundnut sauce & 1330 & 550 & 34 & 910 & 150 & 12 \\
\hline Kucha & Kucha leaf sauce & 990 & 430 & 11 & 510 & 200 & 4 \\
\hline Tio + njeng dajiwo & Groundnut and pumpkin sauce & 200 & 90 & 10 & 360 & 130 & 5 \\
\hline
\end{tabular}

* Dishes known to contain fish or other special ingredients have not been included; nyelengo and futo generally contain dried baobab leaf.

+ To convert $\mathrm{Ca}$ and $\mathrm{P}$ results to $\mathrm{mmol} / \mathrm{kg}$ divide by 40 and 31 respectively. 
Table 4. The measured calcium and phosphorus contents of fish, as eaten by pregnant and lactating Keneba (The Gambia) women*

(Mean values and standard deviations)

\begin{tabular}{|c|c|c|c|c|c|c|c|}
\hline \multirow[b]{2}{*}{ Mandinka name } & \multirow[b]{2}{*}{ Identification } & & \multicolumn{2}{|c|}{$\begin{array}{c}\mathrm{Ca} \\
(\mathrm{mg} / \mathrm{kg}) \dagger\end{array}$} & \multicolumn{2}{|c|}{$\frac{P}{(\mathrm{mg} / \mathrm{kg}) \dagger}$} & \multirow[b]{2}{*}{$n \neq$} \\
\hline & & & Mean & SD & Mean & SD & \\
\hline \multirow[t]{2}{*}{ Chalo } & \multirow[t]{2}{*}{ Bonga (Shad), Ethmalosa fimbriata } & B & 900 & 310 & 2170 & 370 & 7 \\
\hline & & $\mathrm{D}$ & 3950 & 3340 & 7280 & 2400 & 5 \\
\hline \multirow[t]{2}{*}{ Furo/furundingo } & \multirow[t]{2}{*}{ Tilapia, Tilapia spp. } & B & 490 & 250 & 1380 & 400 & 5 \\
\hline & & $\mathrm{D}$ & 40000 & - & 27000 & - & 1 \\
\hline Kojay-furundingo§ & Tilapia, Tilapia spp. & B & 17600 & - & 9600 & - & 2 \\
\hline Kujalo & Spanish fish, Polynemus quadrifilis & $\mathrm{D}$ & 1770 & 630 & 4090 & - & 3 \\
\hline
\end{tabular}

B, boiled; D, dried

* Only edible portions were analysed (see p. 889).

$\dagger$ To convert $\mathrm{Ca}$ and $\mathrm{P}$ results $10 \mathrm{mmol} / \mathrm{kg}$ divide by 40 and 31 respectively.

\pm Number of separate pooled samples analysed.

$\S$ Extremely small furundingo, eaten whole.

Table 5. The measured calcium and phosphorus contents of fresh leaves as used in the preparation of sauces eaten by pregnant and lactating Keneba (The Gambia) women

\begin{tabular}{|c|c|c|c|c|c|c|}
\hline $\begin{array}{l}\text { Mandinka } \\
\text { name }\end{array}$ & Identification & $\begin{array}{l}\text { Frequency* } \\
(\%)\end{array}$ & $\begin{array}{l}\text { Method of } \\
\text { preparation }\end{array}$ & $\begin{array}{c}\mathrm{Ca} \\
(\mathrm{mg} / \mathrm{kg}) \dagger\end{array}$ & $\begin{array}{c}\mathrm{P} \\
(\mathrm{mg} / \mathrm{kg}) \dagger\end{array}$ & $n \ddagger$ \\
\hline \multirow[t]{2}{*}{ Kucha } & \multirow{2}{*}{ Sour leaf (Hibiscus sabdariffa) } & \multirow[t]{2}{*}{54} & $\mathrm{U}$ & 3540 & 490 & 2 \\
\hline & & & $\mathrm{Wd}$ & 2180 & 370 & 2 \\
\hline \multirow{2}{*}{ Morongo } & \multirow{2}{*}{ African spinach (Amaranthus spp.) } & \multirow[t]{2}{*}{15} & $\mathbf{U}$ & 4330 & 1440 & 2 \\
\hline & & & $\mathrm{Wr}$ & 3900 & 290 & 2 \\
\hline \multirow[t]{2}{*}{ Jambanduro } & \multirow[t]{2}{*}{ Cassia tora } & \multirow[t]{2}{*}{13} & $\mathrm{U}$ & 7050 & 1240 & 3 \\
\hline & & & Wd,B & 4330 & 420 & 1 \\
\hline Nebedayo & Morina oleifera & 6 & $\mathrm{U}$ & 3930 & 3010 & 2 \\
\hline Naa & Baobab (Adansonia digitata) & 2 & $\mathbf{U}$ & 3190 & 890 & 3 \\
\hline Kanjo & Okra (Hibiscus esculentus) & $<1$ & $\mathbf{U}$ & 6460 & - & 2 \\
\hline Nyambo & Cassava (Manihot esculenta) & $<1$ & $\mathrm{U}$ & 2710 & 1110 & 3 \\
\hline Potato & Sweet potato (Ipomoea batatas) & $<1$ & $\mathrm{U}$ & 3470 & 620 & 2 \\
\hline Soso & Cowpea (Vigna unguiculata) & $<1$ & $\mathrm{U}$ & 2450 & - & 2 \\
\hline Njengo & Pumpkin (Cucurbita maxima) & $<1$ & $\mathrm{U}$ & 3640 & - & 2 \\
\hline Kerenkerengo & Corchorus olitorus & $<1$ & $\mathrm{U}$ & 3580 & - & 1 \\
\hline
\end{tabular}

$\mathrm{U}$, untreated; Wd, washed and water discarded; $\mathrm{Wr}$, washed and water retained; $\mathrm{B}$, boiled and water discarded.

* Frequency $(\%)$ of each leaf type used in 116 leaf sauces recorded during preparation.

To convert $\mathrm{Ca}$ and $\mathrm{P}$ results to mmol $/ \mathrm{kg}$ divide by 40 and 31 respectively.

$\$$ No. of separate pooled samples analysed.

commonly used fresh leaves (Table 5) generally contain 2000-4500 mg (50-112 mmol) $\mathrm{Ca} / \mathrm{kg}$ and $300-400 \mathrm{mg}(10-13 \mathrm{mmol}) \mathrm{P} / \mathrm{kg}$ at the time they enter the cooking pot.

As the richest sources of $\mathrm{Ca}$ in the Keneba diet are minor foods and flavourings, the $\mathrm{Ca}$ intake of an individual would be predicted to depend more on the cooking habits of the family than on the availability of major food items. Table 6 illustrates the observed frequency of use, and the amounts added, of three Ca-rich ingredients in six common dishes. Local salt, although added in only small quantities, is an ingredient of most dishes and makes a sizeable contribution to foods that otherwise contain very little $\mathrm{Ca}$. Most of 
Table 6. The estimated contribution $(\mathrm{mg} / \mathrm{kg})^{*}$ of three calcium-rich flavourings to the $\mathrm{Ca}$ content of selected dishes eaten by pregnant and lactating Keneba (The Gambia) women

\begin{tabular}{|c|c|c|c|c|c|c|c|c|c|c|c|c|c|c|}
\hline \multirow[b]{2}{*}{ Dish } & \multirow[b]{2}{*}{$n^{\dagger}$} & \multirow[b]{2}{*}{$\mathrm{Ca} \ddagger$} & \multicolumn{4}{|c|}{ Salt } & \multicolumn{4}{|c|}{ Dried fish } & \multicolumn{4}{|c|}{ Dried leaf } \\
\hline & & & W & $\mathrm{F}$ & $\mathrm{C}$ & A & W & $\mathrm{F}$ & $\mathrm{C}$ & A & W & $\mathrm{F}$ & $\mathrm{C}$ & A \\
\hline Tia durango & 220 & 140 & 25 & 81 & 70 & 60 & 43 & 13 & 650 & 80 & 9 & 14 & 160 & 20 \\
\hline Kucha & 51 & 900 & 37 & 91 & 100 & 90 & 48 & 22 & 720 & 160 & 21 & 20 & 380 & 80 \\
\hline Jambo & 53 & 1280 & 18 & 92 & 50 & 50 & 26 & 9 & 390 & 40 & 25 & 4 & 450 & 20 \\
\hline Vegetable stew & 62 & 140 & 52 & 85 & 140 & 120 & 40 & 5 & 600 & 30 & - & 0 & - & 0 \\
\hline Bukolo & 23 & 130 & 19 & 83 & 50 & 40 & 16 & 22 & 240 & 50 & 19 & 39 & 340 & 130 \\
\hline Nyankatango & 49 & 70 & 12 & 100 & 30 & 30 & 17 & 35 & 260 & 90 & - & 0 & - & 0 \\
\hline
\end{tabular}

$\mathrm{W}$, mean weight $(\mathrm{g} / \mathrm{kg}$ ) of ingredient added, when used; $\mathrm{F}$, percentage of observed preparations that contained the ingredient; $\mathrm{C}, \mathrm{Ca}(\mathrm{mg} / \mathrm{kg})$ contributed by ingredient, when used; $\mathrm{A}$, estimated contribution of ingredient $(\mathrm{mg} / \mathrm{kg})$ to average $\mathrm{Ca}$ content of dish $(\mathrm{C} \times \mathrm{F} / 100)$.

* To convert to $\mathrm{mmol} \mathrm{Ca} / \mathrm{kg}$ divide by 40 .

$\dagger$ No. of observed preparations of the dish.

$\ddagger$ Estimated $\mathrm{Ca}$ content $(\mathrm{mg} / \mathrm{kg}$ ) of the plain dish (no salt or other Ca-rich condiments).

the $\mathrm{Ca}$ in porridges is derived from added salt. Dried fish and dried baobab leaf increase the $\mathrm{Ca}$ content of a dish by several fold. Fresh fish flesh and dried fish increase the $\mathrm{Ca}$ content of sauces by a similar amount. Locust beans increase the amount of $\mathrm{Ca}$ in a dish by about $200 \mathrm{mg} / \mathrm{kg}(5 \mathrm{mmol} / \mathrm{kg})$ but as they are used infrequently they contribute little to total $\mathrm{Ca}$ intakes. Most other minor ingredients, such as onion, chili, tomato and cereal flour, contribute little to $\mathrm{Ca}$ intakes.

\section{Unusual sources of calcium}

Two possible sources of $\mathrm{Ca}$ that had not been recorded in earlier dietary assessments were identified during interviews with villagers. The first were certain soils that a few individuals, especially children and pregnant women, chew on rare occasions. Samples from three particularly favoured patches of earth had mean and SD mineral content $(\mathrm{mg} / \mathrm{kg})$ as follows: Ca 280 (SD 50), P 120 (SD 10) (7.0 (SD 1.3) and 4.4 (SD 0.3) $\mathrm{mmol} / \mathrm{kg}$ respectively). Two samples of 'edible' material from termite hills had the following values $\mathrm{Ca} 430$, $1960 \mathrm{mg} / \mathrm{kg}(11,49 \mathrm{mmol} / \mathrm{kg}) ; \mathrm{P} 170,370 \mathrm{mg} / \mathrm{kg}(5,12 \mathrm{mmol} / \mathrm{kg})$ respectively. A typical portion size is $5-10 \mathrm{~g}$. The contribution of geophagy to $\mathrm{Ca}$ intakes in Keneba is likely, therefore, to be extremely small.

The second possible source was baobab fruit (sito), eaten as a snack. Many women occasionally chew the dry, sherbert-like flesh of the baobab fruit when in season (December-April). The seeds are not eaten. To assess the contribution that baobab fruit might make to $\mathrm{Ca}$ intakes, forty-nine pregnant and lactating women were interviewed about the frequency and quantity of sito eaten in season. Of these women, $81 \%$ stated that they chewed a small amount of baobab at least once weekly, with $40 \%$ having some every day. The average snack size, after removal of seeds, was $13 \mathrm{~g}$. Such a snack provides $50 \mathrm{mg}$ $\mathrm{Ca}$ (Table 2). After taking frequency of consumption into account, the maximum likely contribution of baobab fruit to average Ca intakes was estimated at $30 \mathrm{mg} / \mathrm{d}(0.75 \mathrm{mmol} / \mathrm{d})$ in season or $10 \mathrm{mg} / \mathrm{d}(0.25 \mathrm{mmol} / \mathrm{d})$ over the year as a whole.

\section{Calcium and phosphorus intakes of pregnant and lactating women in Keneba 1978-9}

The daily $\mathrm{Ca}$ and $\mathrm{P}$ intakes of pregnant and lactating Keneba women in 1978-9 are given in Table 7. The average $\mathrm{Ca}$ and $\mathrm{P}$ intakes for all women measured over the 12 months were 
Table 7. The estimated daily intake of calcium and phosphorus by Keneba (The Gambia) women in 1978-9

(Mean values and standard deviations)

\begin{tabular}{|c|c|c|c|c|c|}
\hline & \multirow{2}{*}{$\begin{array}{c}\text { No of } \\
\text { subjects }\end{array}$} & \multicolumn{2}{|c|}{$\begin{array}{c}\mathrm{Ca} \\
(\mathrm{mg} / \mathrm{d}) \ddagger\end{array}$} & \multicolumn{2}{|c|}{$\begin{array}{c}P \\
(\mathrm{mg} / \mathrm{d}) \ddagger\end{array}$} \\
\hline & & Mean & SD & Mean & $\mathrm{SD}$ \\
\hline \multicolumn{6}{|l|}{ All year } \\
\hline Pregnant women & 75 & 404 & 133 & 861 & 257 \\
\hline Lactating wornen & 124 & 387 & 93 & 903 & 192 \\
\hline Total & 199 & 394 & 110 & 887 & 219 \\
\hline \multicolumn{6}{|l|}{$\begin{array}{l}\text { July-October } \\
\text { (rainy season) }\end{array}$} \\
\hline Pregnant women & 41 & 455 & 158 & 796 & 268 \\
\hline Lactating women & 85 & 409 & 152 & 765 & 160 \\
\hline Total & 126 & 424 & 155 & 775 & 201 \\
\hline \multicolumn{6}{|c|}{$\begin{array}{l}\text { November-February } \\
\text { (post-harvest dry season) }\end{array}$} \\
\hline Pregnant women & 51 & $365^{* *}$ & 136 & 851 & 262 \\
\hline Lactating women & 91 & $366^{*}$ & 117 & $975 * * * \dagger \dagger$ & 284 \\
\hline Total & 142 & $365^{* * *}$ & 124 & $931^{* * *}$ & 282 \\
\hline \multicolumn{6}{|c|}{$\begin{array}{l}\text { March-June } \\
\text { (pre-harvest dry season) }\end{array}$} \\
\hline Pregnant & 55 & $364 * *$ & 120 & 850 & 264 \\
\hline Lactating women & 122 & $363^{*}$ & 81 & $904^{* * *}$ & 193 \\
\hline Total & 177 & $364^{* * *}$ & 94 & $888 * * *$ & 218 \\
\hline
\end{tabular}

Mean values were significantly different from those obtained in July-October $(t$ test $):{ }^{*} P<0 \cdot 05,{ }^{* *} P<0 \cdot 01$, *** $P<0.001$.

Mean values were significantly different from those of pregnant women in the same season $(t$ test $)+P<0.01$.

¥ To convert $\mathrm{Ca}$ and $\mathrm{P}$ results to $\mathrm{mmol} / \mathrm{d}$ divide by 40 and 31 respectively.

$\S$ May-June 1978 and March-April 1979.

394 and $887 \mathrm{mg} / \mathrm{d}(9.9$ and $28.6 \mathrm{mmol} / \mathrm{d})$ respectively. Including an allowance for baobab fruit raised the $\mathrm{Ca}$ intake estimate to $404 \mathrm{mg} / \mathrm{d}(10 \cdot 1 \mathrm{mmol} / \mathrm{d})$. No significant difference was observed in $\mathrm{Ca}$ intake between pregnant and lactating mothers at any time of the year. In contrast, the $\mathrm{P}$ intakes of pregnant women were lower than those of lactating women during the dry seasons. The Ca intake of all women was significantly higher in the rainy season than in the two dry seasons, while $P$ intakes were lower.

The contributions of various foods to Ca intakes in 1978-9 are illustrated in Fig. 1. The predominant sources of $\mathrm{Ca}$ were leaves, particularly dried baobab leaf, fish, cereals, groundnuts and salt. Cereals, despite low contents of $\mathrm{Ca}$, provided $12 \%$ of $\mathrm{Ca}$ intakes as a result of the large amounts of these foods consumed. Milk accounted for only $5 \%$ of $\mathrm{Ca}$ intakes.

Small changes in dietary practice have occurred in Keneba since 1979. In the intervening years rainfall has become less restricted, the cultivation of garden vegetables has increased and rice has become more popular. However, it is unlikely that any of these changes has had any substantial impact on average $\mathrm{Ca}$ and $\mathrm{P}$ intakes.

\section{DISCUSSION}

The present study has demonstrated that the Ca intakes of Keneba women average about $400 \mathrm{mg} / \mathrm{d}(10 \mathrm{mmol} / \mathrm{d})$ during pregnancy and lactation. These intakes are considerably lower than intakes of pregnant and lactating British women (Black et al. 1986; Schofield 


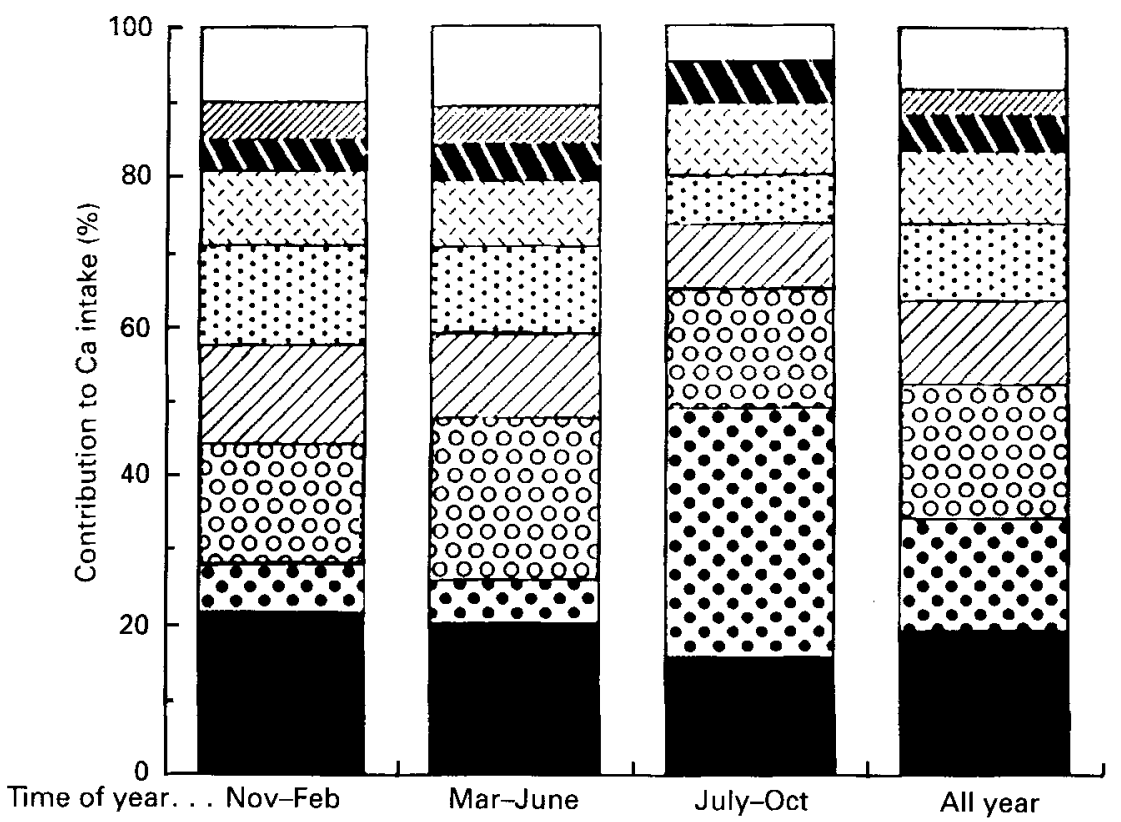

Fig. 1. Contribution of various foods to the Ca intakes of pregnant and lactating Keneba (The Gambia) women,

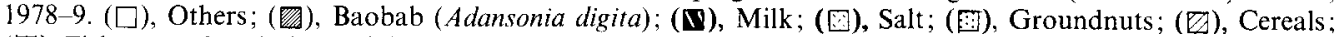
(영), Fish, wet +dry; ( $\mathbf{0})$, Fresh leaves; $(\mathbf{\square})$, Dried baobab leaf. For details of diet, see Tables 1 and 2 and Results.

et al. 1989) and are only about one-third of the reference values given in the UK (Department of Health, 1991) and by the Food and Agriculture Organization/World Health Organization (1962). Further, as the diet is based on cereals, groundnuts and leaves, foods that are rich in phytates and oxalates, the proportion of dietary $\mathrm{Ca}$ absorbed may be low (Allen, 1982).

$P$ intakes in Keneba were shown to average about $900 \mathrm{mg} / \mathrm{d}(30 \mathrm{mmol} / \mathrm{d})$, a somewhat lower intake than that measured in the UK $(1200-1300 \mathrm{mg} / \mathrm{d})$ from household food purchase data (Department of Health, 1991). The intake of P by Keneba women varied between seasons and between pregnant and lactating women in a similar manner to energy intakes (Paul \& Muller, 1980; Prentice et al. 1981).

Recent studies have shown that, despite the rigorous nature of the dietary assessments, energy intakes measured in Keneba do not agree with estimates based on measurements of energy expenditure (Lawrence \& Whitehead, 1988; Singh et al. 1989). Dietary estimates are approximately $70 \%$ of those based on energy expenditure with the greatest divergence occurring in the wet season. The exact reason for the discrepancy is unclear but is likely to be due to inaccuracies in the intake estimates. It is possible, therefore, that $P$ intakes may be underestimated in the present study by a similar amount since the major energyproviding foods are those that are richest in $\mathrm{P}$ (assuming a $30 \%$ shortfall raises average $\mathrm{P}$ intakes to $1270 \mathrm{mg} / \mathrm{d}(41 \mathrm{mmol} / \mathrm{d}))$. It is unlikely, however, that Ca estimates are affected to the same extent, as the main dietary sources of energy are not rich in $\mathrm{Ca}$. If, for example, it is assumed that the discrepancy in energy balance was due to under-reporting of the consumption of groundnuts, the most common energy-rich snack food, the measured $\mathrm{Ca}$ intake would be raised to $450 \mathrm{mg} / \mathrm{d}(11.25 \mathrm{mmol} / \mathrm{d})$, while a similar underestimation of the main energy-providing dish, rice and tia durango, would increase the value to $465 \mathrm{mg} / \mathrm{d}$ $(11.6 \mathrm{mmol} / \mathrm{d})$. If it were assumed, however, that the energy shortfall was due to under- 
reporting of all components of the diet, estimated $\mathrm{Ca}$ intakes would still only rise to $570 \mathrm{mg} / \mathrm{d}(14.25 \mathrm{mmol} / \mathrm{d})$. It can be appreciated, therefore, that, despite the likely inaccuracies of the food intake methodology, $\mathrm{Ca}$ intakes of rural Gambian women undoubtedly are low throughout pregnancy and lactation.

The consequences of such low intakes of $\mathrm{Ca}$ are not known. Recent studies in Keneba have demonstrated that Gambian women attain peak bone mass later (Prentice et al. 1991) and have lower breast-milk $\mathrm{Ca}$ concentrations and $\mathrm{Ca}: \mathrm{P}$ values than British women (Laskey et al. 1990, 1991). However, the reported incidence of osteoporosis in The Gambia is low (Prentice et al. 1991). Detailed supplementation studies are required to determine whether low intakes of $\mathrm{Ca}$ during pregnancy and lactation such as those observed in Keneba are sufficient to support optimal foetal and infant growth without compromising the maternal skeleton.

J.S. and M.A.L. were successive holders of the Rank-Widdowson Fellowship supported by the Rank Prize Funds. The authors thank Dr E. M. Widdowson FRS, Dr R. G. Whitehead and The Rank Prize Funds for their support and encouragement. They also thank Mrs S. M. V. Levitt for computer processing, Mr P. M. V. John for helpful technical advice and the staff of the Dunn Nutrition Unit, Keneba for field work. They are particularly grateful to all the women who participated so cheerfully in this study.

\section{REFERENCES}

Allen, L. H. (1982). Calcium bioavailability and absorption: a review. American Journal of Clinical Nutrition 35, $783-808$.

Baker, P. P. \& Mazess, R. B. (1963). Calcium: unusual sources in the Highland Peruvian diet. Science 142 , $1466-1467$.

Black, A. E., Wiles, S. J. \& Paul, A. A. (1986). The nutrient intakes of pregnant and lactating mothers of good socio-economic status in Cambridge, UK: some implications for recommended daily allowance of minor nutrients. British Journal of Nutrition 56, 59-72.

Brand, J. C., Cherikoff, V., Lee, A. \& McDonnell, J. (1982). Nutrients in important bushfoods. Proceedings of the Nutrition Society of Australia 7, 50-54.

Department of Health (1991). Dietary Reference Values for Food Energy and Nutrients for the United Kingdom. Report of the Panel on Dietary Reference Values of the Commintee on Medical Aspects of Food Policy. Report on Health and Social Subjects no. 41. London: H.M. Stationery Office.

Eaton, S. B. \& Konner, M. (1985). Palcolithic nutrition. A consideration of its nature and current implications. New England Journal of Medicine 312, 283-289.

Eaton, S. B. \& Nelson, D. A. (1991). Calcium in evolutionary perspective. American Journal of Clinical Nutrition $54,281 \mathrm{~S}-287 \mathrm{~S}$.

Food and Agriculture Organization/US Department of Health, Education and Welfare (1968). Food Composition Tables for Use in Africa. Bethesda: National Center for Chronic Disease Control.

Food and Agriculture Organization/World Health Organization (1962). Calcium Requirements. Report of an FAO/WHO Expert Group. Rome: FAO.

Harris, R. S. (1945). An approach to the nutrition problems of other nations. Science 102, 42-44.

Hongo, T., Suzuki, T., Ohtsuka, R., Kawabe, T., Inaoka, T. \& Akimichi, T. (1989). Element intake of the Gidra in lowland Papua: inter-village variation and the comparison with contemporary levels in developed countries. Ecology of Food and Nutrition 23, 293-309.

Hudson, G. J., John, P. M. V. \& Paul, A. A. (1980). Variation in the composition of Gambian foods: the importance of water in relation to energy and protein content. Ecology of Food and Nutrition 10, 9-17.

Laskey, M. A., Prentice, A., Shaw, J., Zachou, T., Ceesay, S. M., Vasquez-Velasquez, L. \& Fraser, D. R. (1990). Breast-milk calcium concentrations during prolonged lactation in British and rural Gambian mothers. Acta Paediatrica Scandinavica 79, 507-512.

Laskey, M. A., Dibba, B. \& Prentice, A. (1991). Low ratios of calcium to phosphorus in the breast-milk of rural Gambian mothers. Acta Paediatrica Scandinavica 80, 250-251.

Lawrence, M. \& Whitehead, R. G. (1988). Physical activity and total energy expenditure of child-bearing Gambian village women. European Journal of Clinical Nutrition 42, 145-160.

McCrae, J. E. \& Paul, A. A. (1979). Foods of Rural Gambia. Cambridge: Dunn Nutrition Unit.

Norton, H. H., Hunn, E. S., Martinsen, C. S. \& Keely, P. B. (1984). Vegetable food products of the foraging economies of the Pacific Northwest. Ecology of Food and Nutrition 14, 219-228. 
Paul, A. A. \& Muller, E. M. (1980). Seasonal variations in dietary intake in pregnant and lactating women in a rural Gambian village. In Maternal Nutrition during Pregnancy and Lactation, pp. 105-116 [H. Aebi and R. Whitehead, editors]. Bern: Hans Huber.

Paul, A. A. \& Southgate, D. A. T. (1978). Mc Cance and Widdowson's The Composition of Foods, 4th ed. London: H.M. Stationery Office.

Platt, B.S. (1962). Tables of Representative Values of Foods Commonly Used in Tropical Countries. Medical Research Council Special Report Series no. 302. London: H.M. Stationery Office.

Prentice, A. (1991). Functional significances of marginal calcium deficiency. In Modern Lifestyles, Lower Energy Intake and Micronutrient Status, pp. 139-154 [K. Peitrzik, editor]. London: Springer-Verlag.

Prentice, A., Shaw, J., Laskey, M. A., Cole, T. J. \& Fraser D. R. (1991). Bone mineral content of British and rural Gambian women aged 18-80+ years. Bone and Mineral 12, 201-214.

Prentice, A. M. (1985). Maternal and Child Publications 1974-1984. Cambridge: Dunn Nutrition Unit.

Prentice, A. M., Whitehead, R. G., Roberts, S. B. \& Paul, A. A. (1981). Long-term energy balance in childbearing Gambian women. American Journal of Clinical Nutrition 34, 2790-2799.

Pun, K. K., Chan, L. W. L., Chung, V. \& Wong, F. H. W. (1991). Calcium content of common food items in Chinese diet. Calcified Tissue International 48, 153-156.

Schofield, C., Stewart, J. \& Wheeler, E. (1989). The diets of pregnant and post-pregnant women in different social groups in London and Edinburgh: calcium, iron, retinol, ascorbic acid and folic acid. British Journal of Nutrition 62, 363-377.

Singh, J. S., Prentice, A. M., Diaz, E., Coward, W. A., Ashford, J., Sawyer, M. \& Whitehead, R. G. (1989). Energy expenditure of Gambian women during peak agricultural activity measured by the doubly-labelled water method. British Journal of Nutrition 62, 315-329

Truswell, A. S., Irwin, T., Beaton, G. H., Haenel, H., Hejda, S., Hou, X.-C., Leveille, G., Morava, E., Pedersen, J. \& Stephen, J. M. L. (1983). Recommended dietary intakes around the world. Nutrition Abstracts and Reviews 53, $1075-1119$.

Wehmeyer, A. S. (1966). The nutrient composition of some edible wild fruits found in the Transvaal. South African Medical Journal 40, 1102-1104.

Wehmeyer, A. S., Lee, R. B. \& Whiting, M. (1969). The nutrient composition and dietary importance of some foods eaten by the Kung Bushmen. South African Medical Journal 43, 1529-1530.

West, C. E., Pepping, F. \& Temalilwa, C. R. (1988). The Composition of Foods Commonly Eaten in East Africa. Wageningen: Wageningen Agricultural University. 